\title{
Listeria seeligeri
}

National Cancer Institute

\section{Source}

National Cancer Institute. Listeria seeligeri. NCI Thesaurus. Code C86503.

A species of facultatively anaerobic, Gram positive, rod shaped bacteria in the phylum Firmicutes. This species is motile by peritrichous flagella, asporogenous, catalase positive, oxidase negative, produces acid from $D$ glucose and $D$ xylose and hydrolyzes esculin. L. seeligeri is found in soil and is regarded as nonpathogenic. 